\title{
The origin and demise of cratonic lithosphere: a geochemical perspective from the Tanzanian craton
}

\author{
Lee, C.-T. ${ }^{1}$ and Rudnick, R. L. ${ }^{1}$
}

1. Department of Earth and Planetary Sciences, Harvard University, Cambridge, MA 02138, USA

Geologic and geochemical studies suggest that cratons are underlain by an anomalously thick, cold lithosphere and that such lithosphere can be stable over timescales greater than two billion years. Low temperatures increase density, hence decrease the buoyancy of the lithosphere; if cold enough, such lithosphere would be rapidly entrained into the convecting mantle. The longevity of cratonic roots, however, requires an additional factor that can compensate for the increased density caused by colder temperatures. One possibility is that cratonic lithosphere is intrinsically less dense than the surrounding mantle due to its more depleted chemical composition (Jordan, 1978), leading to the popular notion that cratonic roots are regions of tectonic stability immersed within a mobile and actively convecting mantle. It is thus important to address how cratonic mantle forms and evolves through time, and moreover, how cratonic mantle survives or is destroyed in regions of continental breakup or collision.

We report here geochemical and petrological studies of mantle xenoliths collected from Labait, a Quaternary olivine-melilitite volcano located south of Mount Hanang on the northeastern edge of the Tanzanian craton (Dawson et al., 1996). Labait is an attractive location to study the formation and evolution of cratonic mantle for several reasons. First, its proximity to regions of active rifting make it a unique site to assess the effects of rifting on destabilizing cratonic mantle. Secondly, Re-Os systematics indicate that cratonic mantle up to $2.8 \mathrm{Ga}$ is still present beneath Tanzania, despite being surrounded by active rifting (Chesley et al., 1998); this allows us to interpret our results in the context of the formation of lithosphere. Thirdly, our research coincides with ongoing geophysical studies in the same region (Ritsema et al., 1998), so we can compare our results to tomographic images of the craton and rift. Finally, unlike most other cratonic xenolith suites, the Quaternary age of Labait volcano gives a window to present-day mantle so that we can make direct comparisons between geochemical and geophysical data sets.

\section{Samples}

Systematic sampling yielded the following xenolith demographics at Labait $(n=117): 75 \%$ cumulate peridotites (mostly dunitic), 22\% residual peridotites, and $<3 \%$ granulites, glimmerites and pyroxenites. Thirty-seven fresh peridotites consisting mostly of residual dunites, harzburgites, low-clinopyroxene lherzolites, and wehrlites were studied in detail. Primary phases include olivine, orthopyroxene, clinopyroxene (mostly in garnet-bearing samples), spinel, chromite, garnet (often completely kelyphitized), and phlogopite. Secondary phases from metasomatic fluids or the host lava include phlogopite, clinopyroxene, iron oxides, sulfides, rutile, zircon, nepheline, perovskite, calcium carbonate, and harmotome. Zircon from a metasomatic vein in one sample gives a Pleistocene age (Rudnick et al., 1998), which constrains the timing of at least one phase of metasomatism to be just prior to xenolith entrainment.

\section{Results}

Garnet peridotites from the Kaapvaal lithosphere are known to be highly enriched in silica and orthopyroxene, unlike asthenospheric mantle (Fig. 1). This difference has been used to argue that there is a fundamental difference in the origin of cratonic and asthenospheric mantle. The Tanzanian lithosphere appears to be slightly silica-enriched as shown in a modal olivine versus Mg\# 
of olivine plot, but the degree of enrichment is not as significant as seen beneath Kaapvaal (Boyd, 1989). Note that most of the Labait garnet-bearing peridotites show relatively low silica-enrichment and plot closer to the "oceanic trend". Modal olivine correlates negatively with temperature, and $\mathrm{FeO}, \mathrm{CaO}$, and modal clinopyroxene correlate positively with temperature (Fig. 2). Using temperature as a proxy for depth, it is clear that fertility increases systematically with depth.

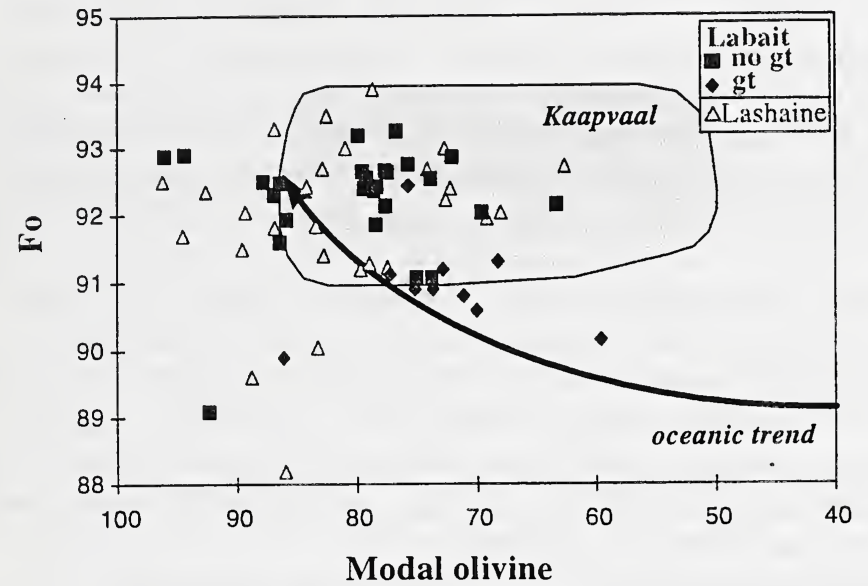

Fig. 1. Forsterite content of olivine versus modal olivine. Modes calculated by least squares regression of whole-rock and mineral chemistry. Plotted are Tanzanian samples from Labait and Lashaine volcanoes, the field of Kaapvaal garnet peridotites, and the "oceanic trend". Labait samples are plotted as solid symbols, with squares and diamonds representing garnetfree and garnet-bearing peridotites, respectively. Lashaine samples plotted as open triangles. Note that Lashaine occurs in the rift.

The simplest interpretation is that there is a variation in the degree of partial melt extraction with depth beneath Tanzania. Systematics between Re-Os and whole-rock chemistry indicate that the entire mantle section beneath Tanzania formed during a single Archean melting event, and has since remained relatively unmodified (Chesley et al., 1998). Therefore, the depth variation in fertility represents a decrease in melt depletion with depth.

Other observations (described below) indicate that Fe-enrichment may be locally superimposed on the overall compositional stratigraphy (Lee and Rudnick, 1997). In one sample, an olivine included within a former garnet is markedly more refractory (Fo92.4) than the groundmass olivine $\left(\mathrm{Fo}_{89.9}\right)$. This olivine inclusion is interpreted to represent the original groundmass composition, which has remained shielded from chemical change by the surrounding garnet. The composition of the groundmass olivine is due to Fe-enrichment of preexisting depleted mantle by silicate melt. This sample also records very recent Re-addition (Chesley et al., 1998), suggesting that the overprinting may be related to East African rifting. The presence of a high percentage of cumulate xenoliths further attests to the passage of melts. In support of local overprinting is the fact that the composition of samples at depth is more heterogeneous, as displayed by the presence of both depleted and fertile garnet peridotites and an increase in variation of clinopyroxene mode with depth (Fig. 2b). Fe-enrichment by infiltrating magmas is expected to lead to spatial heterogeneity because of the tendency for melts to focus into dikes and veins.

\section{Implications for the stability of cratonic lithosphere}

Our observations have implications for the dynamic stability of cratonic lithosphere. The downward increase in fertility is equivalent to an increase in density. We calculated densities using published densities of mineral end-members, their proportions, and their modes, and obtain an average density for the residual peridotites of $3.327 \mathrm{~kg} / \mathrm{m}^{3}$ with deeper samples having densities up to 3.350. For comparison, the average density of Kaapvaal garnet lherzolites is estimated to be 3.353 (Jordan, 1978) - identical to that of the deepest portion of the Tanzanian lithosphere. This density is believed to be enough to counteract the negative buoyancy imposed by the cooler thermal 
state of cratonic lithosphere based on Jordan's isopycnic hypothesis (1978). It thus appears that the original Tanzanian mantle was dynamically stable with respect to the surrounding asthenospheric mantle. It is important to note that the original mantle was also internally stable due to the monotonic increase in density with depth. Whether this density stratigraphy is a direct result of Archean melt extraction or a result of advective turnover within the cratonic mantle after its formation is uncertain.

Although the Tanzanian lithosphere has remained intact for $\sim 3 \mathrm{Ga}$, interaction with magmas associated with the East African Rift has led to an increase in density of the mantle section by local Fe-enrichment and by crystallization of Fe-rich cumulates in veins and dikes. The latter process is likely to be the dominant mechanism for increasing the overall density. Assuming that the base of the mantle section is most prone to interaction with upwelling magmas, addition of $20-30 \%$ Fe-rich cumulates $\left(-3.400 \mathrm{~kg} / \mathrm{m}^{3}\right)$ is required to reduce the positive buoyancy of the mantle to the point of neutral buoyancy $(-3.350)$. If the base of the mantle section continues to interact with the riftrelated magmas, the lithospheric root may become negatively buoyant and delaminate from the overlying craton. The presence of low seismic velocities beneath Labait suggests that the effects of rifting are currently propagating into the craton margins (Ritsema et al., 1998). The high temperatures recorded in the Labait xenoliths are consistent with rift-related heating. The combination of high temperatures and Fe-rich zones will decrease seismic velocities. Once allowed to cool, the Fe-enriched mantle may become gravitationally unstable.
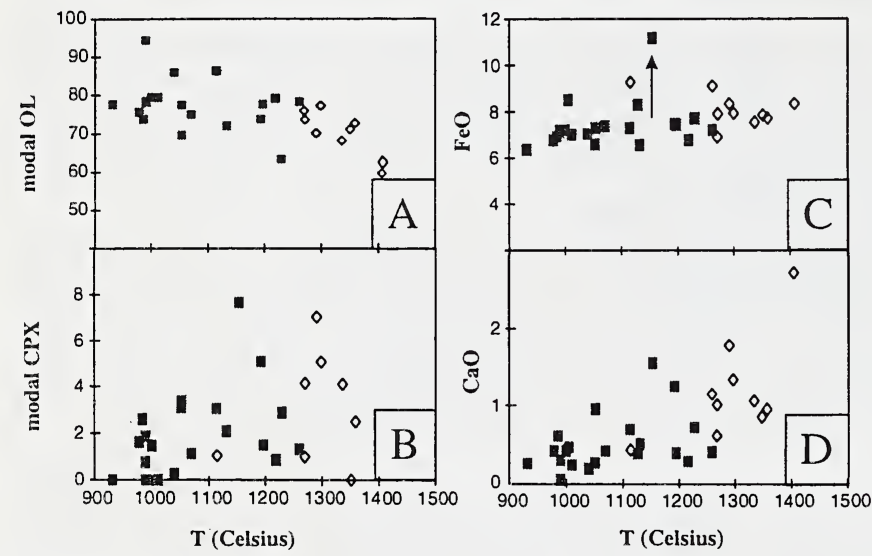

Fig 2. A, B. Modal olivine and clinopyroxene versus temperature. Modes calculated by least squares regression of whole-rock and mineral chemistry. C,D. $\mathrm{FeO}$ and $\mathrm{CaO}$ versus temperature. Note the increase in fertility with temperature, implying a compositional variation with depth. Arrow in $\mathrm{C}$ indicates direction of Fe-enrichment superimposed on the overall trend. Diamonds and squares are gt-bearing and gt-free peridotites from Labait.

\section{References}

Boyd, F. R., 1989, Compositional distinction between oceanic and cratonic lithosphere: Earth and Planetary Sciences Letters, v. 96, p. 15-26.

Chesley, J., Rudnick, R. L., and Lee, C.-T., 1998, Longevity of cratonic mantle beneath an active rift: Re-Os evidence from xenoliths from the Tanzanian East African Rift: this volume.

Dawson, J. B., James, D., Paslick, C., and Halliday, A. M., 1996, Ultrabasic potassic low-volume magmatism and continental rifting in north-central Tanzania: ssociation with enhanced heat flow: Russian Geology and Geophysics, v. 38 , p. $69-81$.

Jordan, T. H., 1978, Composition and development of the continental tectosphere: Nature, v. 274, p. 544-548.

Lee, C.-T. and Rudnick, R. L., 1997, The formation and destruction of cratonic lithosphere: Insights from the Tanzanian craton: American Geophysical Union Fall Abstracts, v. 78, p. 746.

Ritsema, J., Nyblade, A. A., Owens, T. J., Langston, C. A., and VanDecar, J. C., 1998, Upper mantle seismic velocity structure beneath Tanzania, East Africa: Implications for the stability of cratonic lithosphere: submitted to the Journal of Geophysical Research.

Rudnick, R. L., Ireland, T. R., Gehrels, G., Irving, A. J., Chesley, J. T., and Hanchar, J. M. 1998, Dating mantle metasomatism: U-Pb geochronology of zircons in cratonic mantle xenoliths from Montana and Tanzania: this volume. 